\title{
Development and survival of the endocrine hypothalamus and posterior pituitary gland requires the neuronal POU domain factor Brn-2
}

\author{
Marcus D. Schonemann, ${ }^{1,2}$ Aimee K. Ryan, ${ }^{1,4}$ Robert J. McEvilly, ${ }^{1,4}$ Shawn M. O'Connell, ${ }^{1}$ \\ Carlos A. Arias, ${ }^{3}$ Kristin A. Kalla, ${ }^{1}$ Peng Li, ${ }^{1,2}$ Paul E. Sawchenko, ${ }^{3}$ and Michael G. Rosenfeld ${ }^{1,5}$ \\ ${ }^{1}$ Eukaryotic Regulatory Biology Program, Howard Hughes Medical Institute, ${ }^{2}$ Graduate Program in Biomedical Sciences, \\ University of California, San Diego, Department and School of Medicine, La Jolla, California 92093-0648; and Laboratory of \\ Neuronal Structure and Function, The Salk Institute for Biological Sciences, San Diego, California 92186-5800 USA
}

\begin{abstract}
Neurons comprising the endocrine hypothalamus are disposed in several nuclei that develop in tandem with their ultimate target the pituitary gland, and arise from a primordium in which three related class III POU domain factors, Brn-2, Brn-4, and Brn-1, are initially coexpressed. Subsequently, these factors exhibit stratified patterns of ontogenic expression, correlating with the appearance of distinct neuropeptides that define three major endocrine hypothalamic cell types. Strikingly, deletion of the Brn-2 genomic locus results in loss of endocrine hypothalamic nuclei and the posterior pituitary gland. Lack of Brn-2 does not affect initial hypothalamic developmental events, but instead results in a failure of differentiation to mature neurosecretory neurons of the paraventricular and supraoptic nuclei, characterized by an inability to activate genes encoding regulatory neuropeptides or to make correct axonal projections, with subsequent loss of these neurons. Thus, both neuronal and endocrine components of the hypothalamic-pituitary axis are critically dependent on the action of specific POU domain factors at a penultimate step in the sequential events that underlie the appearance of mature cellular phenotypes.
\end{abstract}

[Key Words: Brn-2; POU domain; endocrine hypothalamus; posterior pituitary; neurosecretory neurons; cell diversification]

Received September 27, 1995; revised version accepted October 26, 1995.

A fundamental aspect of the development of complex organ systems is a requirement for precise temporal and spatial coordination in the genesis of tissues of distinct embryonic origins to form functional units required for physiological homeostasis and survival. Such a requirement is particularly well exemplified in mammalian development in the formation of the hypothalamic-pituitary axis. This neuroendocrine system integrates signals from the periphery and brain to modulate production and secretion of regulatory hormones by specific pituitary cell types, critically serving to maintain homeostasis in response to stress and diverse signals required for survival of individuals and species (Swanson and Sawchenko 1983; Swanson 1986). In contrast to most regions of the nervous system, specific cell types of the endocrine hypothalamus can be distinguished readily on the basis of their neuropeptide "signatures," recommending these neurons as tractable models for probing the roles of specific families of transcription factors in

\footnotetext{
${ }^{4}$ These authors made equivalent contributions to this work. ${ }^{5}$ Corresponding author.
}

development. The hypothalamus and pituitary gland, which originate from distinct ectodermal primordia (Eagleson and Harris 1990; Andersen and Rosenfeld 1995), exhibit a remarkable degree of developmental coordination, such that the initial activation of peptide expression by neurosecretory neurons coincides not only with the arrival of their axonal projections at the median eminence or the posterior pituitary, but also with the initial appearance of specific receptors for these regulatory neuropeptides. For example, growth hormone-releasing hormone $(G R H)$ appears in the median eminence at the identical time that its receptor appears in nascent somatotropes (Vale et al. 1981; Guillemin et al. 1982; Lin et al. 1992).

The hypothalamus arises from third ventricular neuroepithelium ventral to the hypothalamic sulcus, with neurogenesis occurring over embryonic days 10-18 (E10-E 18$)$ in the rat. Functionally allied neurons are generated sequentially following an outside-in gradient (Alvarez-Bolado et al. 1995), ultimately yielding stratified arrangements of mature neuronal phenotypes in which the generally late-arising neurosecretory cell types come 
to assume a topographic distribution in the most medial, or periventricular, zone of the hypothalamus (Swanson $1986,1987)$. Within this periventricular zone, two distinct neurosecretory systems, comprising multiple cell types distributed over multiple cell groups, are organized in a complex mosaic manner. The magnocellular neurosecretory system includes neurons of the paraventricular hypothalamic (PVH) and supraoptic (SO) nuclei that synthesize the peptide hormones oxytocin $|\mathrm{OT}|$ or arginine vasopressin (AVP), and release them in an activity-dependent manner from axon terminals in the posterior lobe of the pituitary gland; AVP plays important roles in regulating blood pressure, volume, and osmolality, whereas the best known functions of OT are in promoting milk letdown and parturition (Cunningham and Sawchenko 1991). Axons of multiple cell types comprising the parvocellular neurosecretory system deliver neuropeptide products to the median eminence for conveyance via the hypophyseal-portal vasculature to modulate the synthesis and release of tropic hormones of the anterior pituitary (Swanson 1986, 1987). In addition to a subset of magnocellular neurosecretory neurons, the PVH harbors separate populations of parvocellular cells that synthesize corticotropin-releasing hormone (CRH) and thyrotropin-releasing hormone (TRH) that govern pituitary-adrenal and pituitary-thyroid responses, respectively, to stress and metabolic demand. Centered in ventrally contiguous cell groups in the anterior periventricular or the arcuate nuclei are hypophysiotropic neurons that provide the dopaminergic control of prolactin secretion, and somatostatin or GRH, which impart the principal inhibitory and stimulatory regulation of growth hormone dynamics, respectively. A tendency toward topographic segregation of endocrine neuronal phenotypes is most crisply defined in rat, but these essential organizational features are well maintained across species (Swanson and Sawchenko 1983). In addition, several neurochemically (and hence functionally) defined endocrine hypothalamic cell types also produce additional neuropeptides that serve to sculpt overall system function, although these are generally expressed in lesser abundance or in a condition-dependent manner (Sawchenko et al. 1992; Meister 1993).

Genetic and molecular biological approaches have permitted the identification of tissue-specific transcription factors expressed in the forebrain, including the endocrine hypothalamus. The initial forebrain-specific factors identified were novel members of the class III POU gene family, referred to as Brain-1 (Brn-1), Brn-2, Brn-4, and Tst-1/suppressed cAMP-inducible POU (SCIP)/Oct-6 (He et al. 1989; Monuki et al. 1990; Suzuki et al. 1990; Hara et al. 1992; Le Moine and Young 1992; Mathis et al. 19921. A number of other gene families, including homeo domain factors, Pax domain proteins, nuclear receptors, winged-helix proteins, LIM-homeo domain proteins, and helix-loop-helix factors, have been identified subsequently (Boncinelli et al. 1993; Bulfone et al. 1993; Chalepakis et al. 1993; Lai et al. 1993; Price 1993, Dolle et al. 1994; Lee et al. 19951.

The POU domain factors were identified initially with the simultaneous discovery of a pituitary-specific transcription factor, Pit-1 (Bodner et al. 1988; Ingraham et al. 19881, a B-cell-"specific" transcription factor, Oct-2 (Clerc et al. 1988; Ko et al. 1988; Müller et al. 1988; Scheidereit et al. 1988), the ubiquitous octamer-binding protein, Oct-1 (Sturm et al. 1988), and the Caenorhabditis elegans unc-86 gene product (Finney et al. 1988). This gene family contains a novel bipartite DNA-binding structure, referred to as the POU domain (Herr et al. 1988; Assa-Munt et al. 1993; Dekker et al. 1993; Wegner et al. 1993; Klemm et al. 1994; Herr and Cleary 1995). A large family of POU domain factors were identified subsequently (He et al. 1989; Wegner et al. 1993), and partitioned into six classes (POU I-POU VI).

The role of three of the initially described POU domain factors in determining specific cell phenotypes has now been established genetically. Pit-1 serves to function as the critical activator of distal target genes and regulates proliferation or survival, or both, of three anterior pituitary cell types (Li et al. 1990; Lin et al. 1993; Godfrey et al. 1993; Parks et al. 1993; Andersen and Rosenfeld 19951. Unc-86 is required for the commitment of several neuroblast lineages and the specification of various neurons (Finney and Ruvkun 1990), and Oct-2 appears to exert important roles in determining terminal B-cell development and survival (Corcoran et al. 1993). Because each member of the class III POU domain gene family exhibits a distinct, yet overlapping, pattern of expression in the developing and mature nervous system (Alvarez-Bolado et al. 1995), it is tempting to consider the possibility that combinatorial codes of specific class III POU proteins are responsible for determining specific neuronal phenotypes.

In this article, we report that members of the class III POU domain proteins, Brn-1, Brn-2, and Brn-4, are expressed in an overlapping stratified pattern in the developing hypothalamus, correlating with gene activation events required to establish and maintain specific cellular phenotypes. Using a gene-deletion approach, we have established that one member of the class III POU domain factors, Brn-2, although not required for initial cell division and migration events, exerts critical roles in the penultimate stage of endocrine hypothalamus development and in posterior pituitary gland formation. Deletion of Brn-2 results in developmental loss of these structures. Thus, the coordinate development of the hypothalamic-pituitary axis requires parallel actions of at least two distinct classes of POU domain transcriptional reg. ulators.

\section{Results \\ POU III expression patterns and hypothalamic cell phenotypes}

The importance of Pit-1 in pituitary development prompted us to examine the potential roles of the POU III class in development of the hypothalamus, where they are highly expressed. Whole mount in situ hybridization of E8-E12 embryos has revealed Brn-2 expression 
in specific regions of the developing neuraxis. At E8.5, $B r n-2$ is expressed in restricted regions of the neural folds (Fig. 1a). Expression then extends caudally, such that $B r n-2$ is expressed at almost all levels of the developing central nervous system, including the ventral diencephalon from which the hypothalamic neurons arise (Fig. lb). At E10.5, a gap of Brn-2 expression is observed at the midbrain-hindbrain junction. Ultimately, Brn-2 expression becomes restricted to discrete regions of the brain (data not shown; He et al. 1989; Alvarez-Bolado et al. 1995). To begin to define the potential involvement of Brn-2 and the other POU III factors in hypothalamic development, we raised specific antisera against Brn-1, Brn2, Brn-4, and Tst- 1 and investigated their patterns of expression. Overlapping patterns of class III POU domain proteins were observed in many developing brain structures (Figure 1c,d; Alvarez-Bolado et al. 1995; data not shown). Brn-2 is expressed particularly strongly in the PVH and SO nuclei of the mature endocrine hypothalamus (Fig. 1e,f), as is Brn-4 (Fig. 2; data not shown).

Brn-2 protein is detected in regions of the PVH nucleus (Fig. 1), which include the parvocellular neurons that synthesize high levels of CRH and the magnocellular neurons that synthesize AVP and OT (Li et al. 1993). Dual-labeling analyses revealed near complete coexpression of Brn-2 with each of these neuropeptide transcripts (Fig. 1g-i), whereas neither Brn-2 nor Brn-4 was ex- pressed in a significant number of parvocellular neurons that produce TRH (data not shown). In situ hybridization revealed that Brn-2, Brn-4, and Brn-1, but not Tst-1, were expressed at E10-E11, adjacent to the third ventricle in the primordium of the endocrine hypothalamus (data not shown; Alvarez-Bolado et al. 1995). By E13-E14, Brn-1, Brn-2, and Brn-4 proteins exhibited distinctive patterns of specific expression. Both Brn-2 and Brn-4, but not Brn1 , remained colocalized to the region of the developing PVH and SO nuclei, whereas Brn-4 expression extended ventrally to potential precursors of the anterior hypothalamus (Fig. 2A). In contrast, Brn-1-expressing cells were located immediately dorsolaterally in the presumptive zona incerta $(\mathrm{ZI})$; and in a dorsoventral stripe lateral to Brn-4-expressing cells (Fig. 2A; data not shown). On the basis of an estimated cell cycle of $\sim 6-8 \mathrm{hr}$ at the relevant developmental times (Altman and Bayer 1986), Brn-2 is expressed for at least 8 - to 12 -cell cycles before the onset of terminal differentiation events in this area.

Magnocellular neurons also coexpressed Brn-2 and Brn-4 during their migration from the presumptive $\mathrm{PVH}$ nucleus toward their definitive location in the SO nucleus at the base of the hypothalamus (data not shown) and in the mature SO nucleus (Fig. 2C). In the adult hypothalamus, high levels of Brn-2 and Brn-4 gene expression were limited primarily to these two cell groups. $C R H$ transcripts were detected initially in these cells on
Figure 1. Brn-2 expression and coexpression with CRH, OT, and AVP. $(a, b)$ Whole mount in situ hybridization of E8.5 (8-10 somite) and E10.5 mouse embryos with a Brn-2 cRNA probe. At E8.5 (a), Brn-2 is expressed in limited regions of the neural folds. By E10.5 $(b)$, Brn-2 expression extends caudally from the developing forebrain through the developing neural tube. A gap in Brn-2 expression is noted at the midbrain-hindbrain junction. $(c-f)$ Coronal brain sections labeled with an antiserum that detects Brn-2 protein. (c) At E16, there is intense $\mathrm{Brn}-2$ expression in the cortical plate $(\mathrm{cp})$ and the subventricular zone (svz). (d) Brn-2 is expressed in layers II, III, and V of the developing cortex of the p5 mouse. $(e, f)$ Robust Brn-2 expression in the parvocellular and magnocellular neurons of the paraventricular $\left(\mathrm{PVH}_{;} e\right)$ and supraoptic nuclei $(\mathrm{SO} ; f)$. The third ventricle is indicated (V3). $|g-i|$ Adjacent coronal sections of $\mathrm{p} 5$ mouse brains at the level of the paraventricular nucleus showing cellular colocalization of Brn-2 protein (brown) with CRH $\left(g, g^{\prime}\right), \operatorname{AVP}\left(h, h^{\prime}\right)$, and OT $\left(i, i^{\prime}\right)$ transcripts (blue) in the paraventricular nucleus of the hypothalamus. $1 g^{\prime}-$ $\left.i^{\prime}\right)$ Detail of sections shown in $g-i$. Abbreviations: (D) diencephalon; (M) midbrain; (NF) neural fold; (H) hindbrain; (T) telencephalon. $(c-e, g-i) ;$ Bar, $50 \mu \mathrm{m} ;\left(f, g^{\prime}, h^{\prime}, i^{\prime}\right)$ bar, $10 \mu \mathrm{m}$.
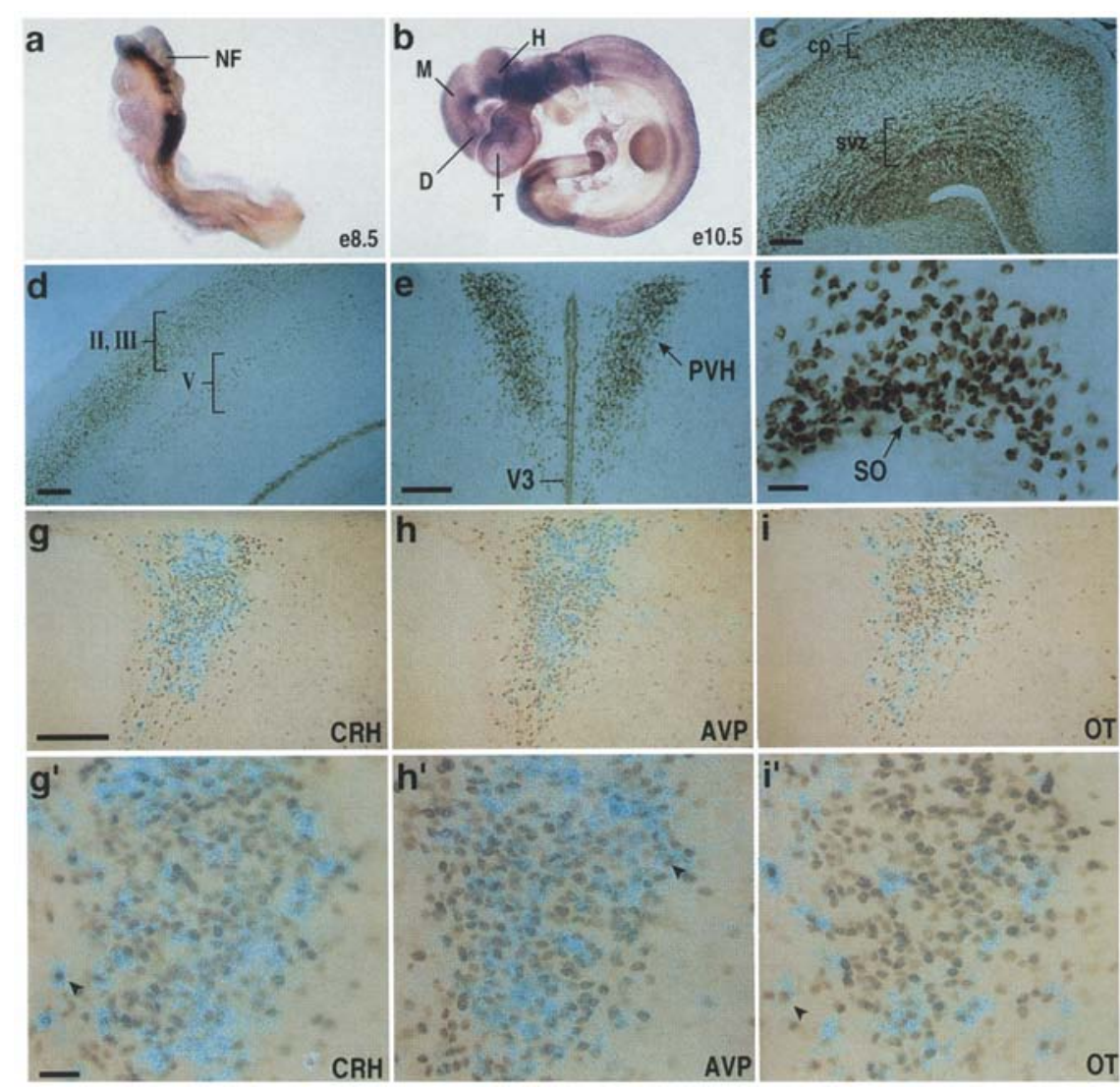
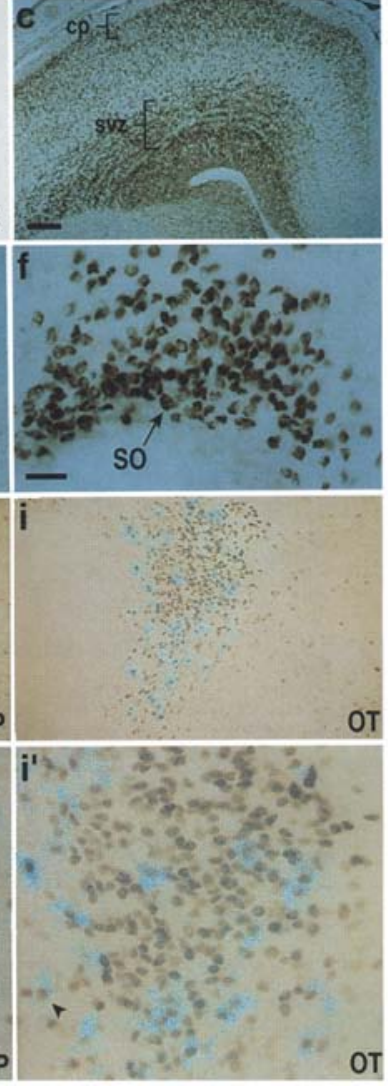
A

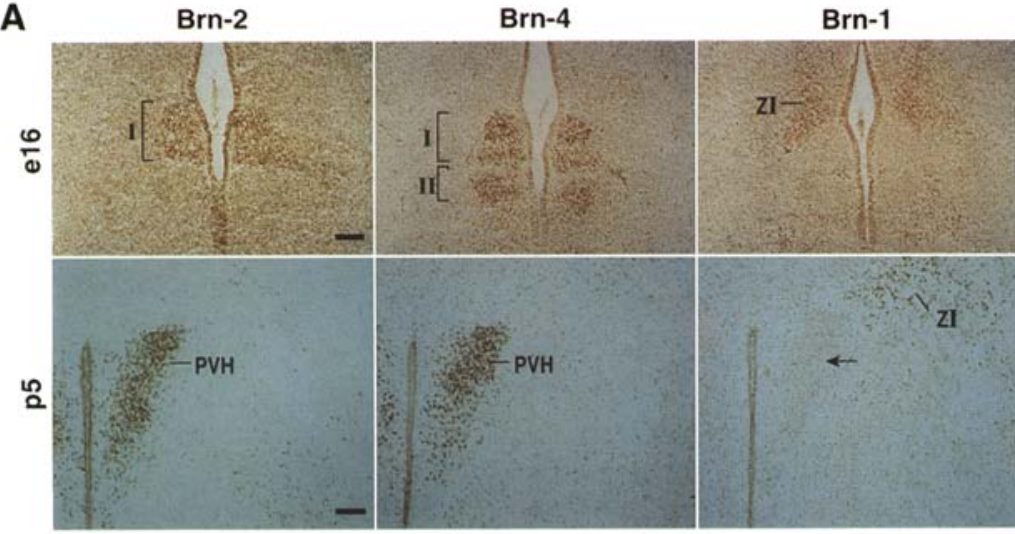

B
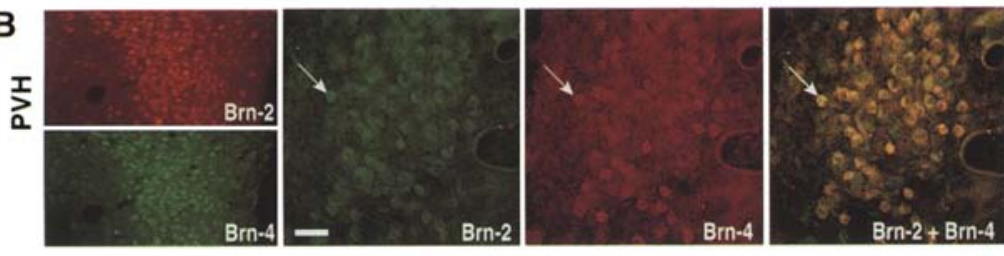

C
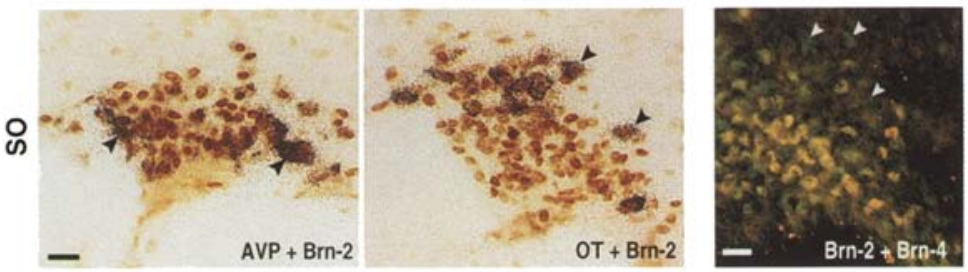

D Reporters:
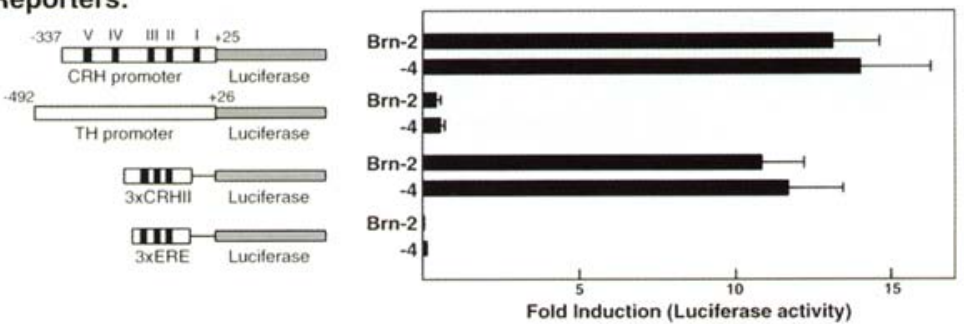

Figure 2. Stratified expression of POU III factors in the developing paraventricular and supraoptic hypothalamic nuclei. $(A)$ Coronal sections at the level of the paraventricular region of the hypothalamus at E16 and p5 labeled with specific antisera against Brn-2 (left), Brn-4 (middle), and Brn-1 (right). Brn-2 and Brn-4 are both expressed in neurons of the nascent paraventricular nucleus of the hypothalamus at E16 (I) and in the paraventricular nucleus of the hypothalamus (PVH) at $\mathrm{p} 5$. At E16, Brn-4-positive neurons are also observed immediately ventral to the paraven. tricular neurons (II). Brn-1 protein is observed in neurons of the zona incerta $(\mathrm{ZI})$ but not in the neurons of the paraventricular nucleus (arrow). $(B) \mathrm{Brn}-2$ and Brn-4 are coexpressed in the paraventricular neurons. Double immunohistochemistry demonstrates Brn-2 (red, top) and Brn-4 (green, bottom) expression in a single section through the paraventricular nucleus. The three remaining panels show the single and double exposures of Brn-2 (green) and Brn-4 (red) in a different section through the paraventricular nucleus at a higher magnification illustrating that coexpression of $\mathrm{Brn}-2$ and $\mathrm{Brn}-4$ is observed in the majority of neurons. One such neuron is indicated by an arrow in the latter three panels. $(C)$ Dorsal-ventral stratification in the supraoptic nucleus of AVP and OT transcripts (black silver grains) in Brn-2 positive neurons (brown). (Far right) A different section through the supraoptic nucleus. Neurons positive for only Brn-2 (green) are located predominantly on the dorsal periphery of the supraoptic nucleus (arrowheads), whereas in ventral aspects Brn-2 and Brn-4 coexpressing neurons /yellow are observed. (D) Both Brn-2 and Brn-4 activate the CRH promoter. Transient cotransfection into CVI cells of a Brn-2 or Brn-4 transcription unit under the control of the CMV promoter with luciferase reporter constructs containing a CRH promoter, a tyrosine hydroxylase promoter (TH promoter), three high-affinity Brn-2-binding sites from the CRH promoter (3xCRHII) or three estrogen response elements (3xERE). Brn- 2 and Brn-4 are virtually identical in activating transcription from the CRH promoter and the $3 \mathrm{xCRHII}$ reporter constructs. Results are expressed as fold stimulation. The CRH-promoter-luciferase construct is 2500 light units in the absence of Brn-2 or Brn-4 expression plasmids. $(A)$ Bar, $50 \mu \mathrm{m} ;(B, C)$ bar, $10 \mu \mathrm{m}$.

E15.5-E16.5, consistent with previous observations (Grino et al. 1989; Alvarez-Bolado et al. 1995). On the basis of their high degree of homology, the capacity of Brn-4, as well as Brn-2, to activate the $C R H$ promoter, which contains multiple high-affinity DNA sites for these proteins (Li et al. 1993) was evaluated. Both Brn-2 and Brn-4 were equivalently capable of activating the $C R H$ gene promoter in transient transfection assays in heterologous cell types (Fig. 2D).

Dual-labeling analyses were used to confirm the apparent coexpression of Brn-2 and Brn-4 in a majority of neurons in the paraventricular and supraoptic nuclei throughout the ontogeny of the endocrine hypothalamus (E13-E19) (Fig. 2B; data not shown), including those expressing $\mathrm{CRH}$. A clear anterodorsal to posteroventral stratification of OT and AVP expression, respectively, was observed in the SO nucleus (Fig. 2C). This correlated with the finding that cells situated anterodorsally tend to express only $\mathrm{Brn}-2$, whereas more posteroventrally disposed neurons express both Brn-2 and Brn-4 (Fig. 2C). Outside of the endocrine hypothalamus, $B r n-2$ and $B r n-1$ exhibit partially overlapping patterns of expression, 
whereas Brn-2 and Brn-4 genes generally exhibit quite distinct patterns of expression (data not shown; He et al. 1989; Alvarez-Bolado et al. 1995).

\section{Loss of maior endocrine hypothalamic cell phenotypes} in Brn-2 $(-1-)$ mice

To investigate the potential roles of these factors in neural development we generated mice homozygous null for the Brn-2 genomic locus using homologous recombination in embryonic stem (ES) cells (Thomas and Capecchi 1987). The targeting vector was designed to remove the entire Brn-2 coding sequence, as well as some $5^{\prime}$ and $3^{\prime}$ flanking information to ensure nonexpression of the gene (Fig. 3A). As shown in Figure 3B, one ES cell line heterozygous for the deleted Brn-2 genomic locus (no. 33) was identified and used to inject blastocysts and obtain chimeric mice that provided germ-line transmission of the deleted Brn-2 genomic allele. Breeding of heterozygous Brn-2 $(+1-)$ mice permitted generation of mice homozygous null for the genomic locus (Fig. $3 \mathrm{Cl}$, and assessment of their phenotype. Brn-2 $(-1-)$ mice (Fig. $3 \mathrm{D}$; data not shown) were born at expected Mendelian ratios (59/262 births), indicating that they were capable of normal embryonic development, and are physically and behaviorally normal at birth. However, these mice failed to exhibit progressive increase in size and weight after postnatal day $3(\mathrm{p} 3)-\mathrm{p} 4$, and by $\mathrm{p} 6$ they were consistently $50 \%$ to $60 \%$ smaller than age-matched littermates and exhibited a hyperkeratotic, flaking epidermis. Approximately $90 \%$ of the Brn-2 $1-1-1$ mice did not survive beyond p6, with the remaining $10 \%$ dying between $\mathrm{p} 9$ and p 10 . Initial examination of all organ systems revealed no gross anatomical abnormalities outside of the central nervous system. Nissl-stained sections across the entire brain revealed no detectable abnormalities in the cortex, hippocampal formation, or other structures outside of the hypothalamus. Furthermore, the expression of specific markers such as Brn-1, Brn-4, and Tst- 1 in nonhypothalamic regions appeared normal in all areas examined by immunohistochemistry procedures, consistent with the unimpaired maturation of Brn-2-expressing neuronal cell types in the absence of functional Brn-2 protein in many regions of the brain /see examples, Fig. 3E).

However, examination of $\mathrm{p} 6$ mice revealed a striking finding. Brn-2 $(-/-)$ mice exhibited a virtually complete failure to express CRH transcripts or protein in the

Figure 3. Targeted disruption of the Brn-2 locus. (A) Schematic representation of the Brn-2 locus (top), the targeting vector (middle), and the Brn-2 null allele (bot tom). Thickened bars indicate regions of genomic DNA homology. Homologous recombination results in the replacement of the entire Brn-2-coding region $(\square$ and $\mathbf{\square})$ and $2.5 \mathrm{~kb}$ of $5^{\prime}$-flanking sequence with a $n e o^{\mathrm{r}}$ cassette. The $3^{\prime}$ external probe (probe A) and an internal probe (neo) used in Southern blot analysis are indicated. Restriction enzymes: (E) EcoRI; (B) BamHI. (B) Analysis of transfected ES cells by Southern blotting using the internal probe (neo) identifies a 4.5-kb BamHI fragment in the mutant allele and probe $A$ identifies a $20-\mathrm{kb}$ EcoRI fragment from the wild-type allele and a $15-\mathrm{kb}$ fragment from the mutant Brn-2 null allele. Results from a wild type, a recombinant ES cell line $\{33 \mid$ and molecular weight marker (std) are shown. (C) PCR determination of genotypes of offspring from heterozygous $F_{1}$ intercrosses using a pair of PCR primers that amplify the $B r n-2$ gene $(500 \mathrm{bp}$ ) and a pair of primers that amplify the neo ${ }^{\mathrm{r}}$ gene $(590 \mathrm{bp})$. Homozygous mutant $B m-2|-1-|$ mice are indicated by an asterisk. (D) A Brn-2-specific antiserum was used to document Brn-2 expression in the orbital cortex of a homozygous wild-type mouse (upper) and the lack of corresponding Brn-2

A

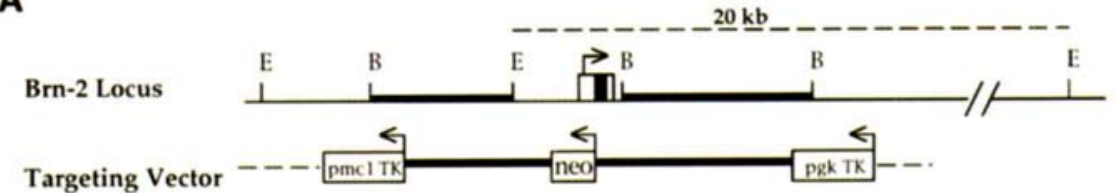

Targeted Locus

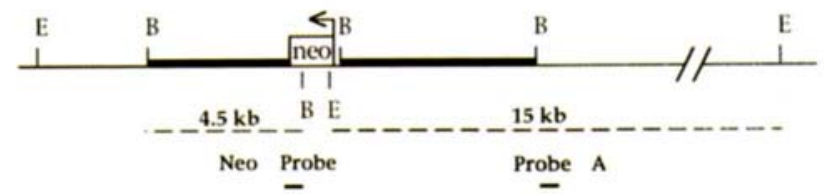

B
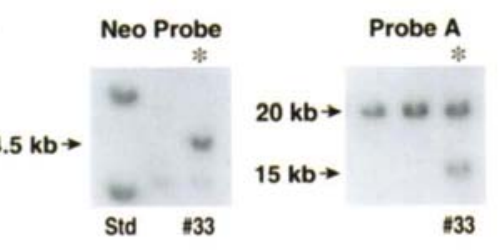

C
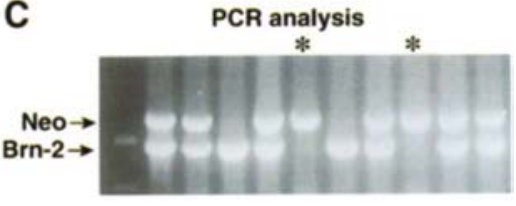

D

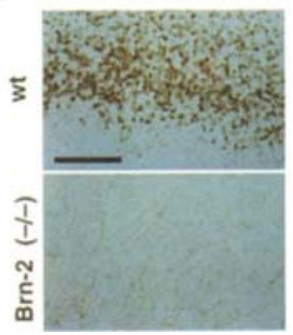

E

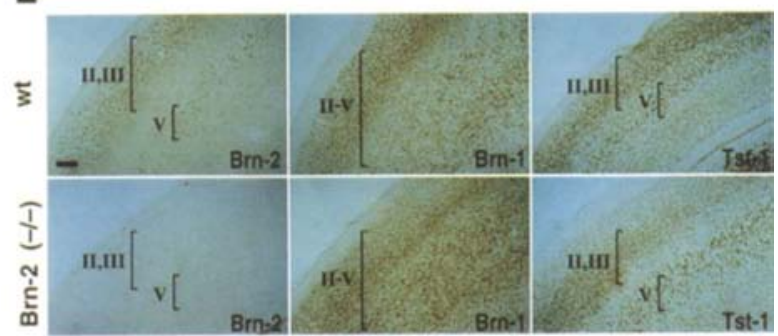

expression in a homozygous mutant mouse (lower). $\mid$ E) Coronal sections of p5 homozygous wild-type $(+1+1$ and homozygous mutant Brn-2 (-1 - | mice showing the expression of Brn-2, Brn-1, and Tst-1 in the cortex. Patterns and levels of expression of Brn-1 and Tst-1 in the cortex is unaffected by deletion of the Brn-2 locus. Bar, $50 \mu \mathrm{m}$. 
PVH nucleus (Fig. 4). CRH expression in other Brn-2negative forebrain regions (e.g., amygdala) was maintained at ostensibly normal levels and topography in Brn-2 $(-/-)$ animals. In parallel, OT and AVP cRNA probes were used to determine whether the mature magnocellular neurons that also express high levels of Brn-2 might exhibit similar alterations in neuropeptide gene expression. Neither OT nor AVP transcripts were detectable in the magnocellular neurons of either the paraventricular or supraoptic hypothalamic nuclei of p $6 \mathrm{Brn}-2$ $(-1-1$ mice (Fig. 4). Expression of AVP in the non-Brn2-expressing cells of the suprachiasmatic nucleus was maintained, indicating that effects were cell specific (Fig. 4). In contrast to a rare cell that maintained $C R H$ gene expression in the paraventricular hypothalamic nucleus, no cells expressing OT or AVP persisted in the postnatal $B r n-2(-/-)$ endocrine hypothalamus.

Specificity of these effects was established by demonstration that the parvocellular neurons of the PVH nucleus that express TRH, but not Brn-2, appeared to be fundamentally intact in the Brn-2 $\mid-/-1$ mice, and exhibited robust TRH gene expression (Fig. 5). Similar results were obtained with respect to the anterior periventricular neurons expressing somatostatin, and neurons of the arcuate nucleus that express GRH, neither of which express Brn-2. The density of detectable $\mathrm{TRH}$-, somatostatin-, and GRH-expressing endocrine hypothalamic neurons seen in Brn-2 $|-|-\mid$ mice tended toward the low end of the normal range, and the expression patterns of these neuropeptide genes (particularly that of TRH) in the paraventricular nucleus showed a somewhat disordered topography, presumably as a result of the loss of three sizable and contiguous cell populations (see belowl. No major direct or indirect consequences of Brn-2 gene deletion were observed in neurosecretory neurons that populate the periventricular zone of the hypothalamus, apart from the virtually complete failure to activate CRH, OT, and AVP expression in neuroendocrine cells, specifically. Even the relatively small complements of somatostatin- and GRH-producing neuron present in the wild-type PVH nucleus remained intact in the Brn-2 $1-1$ - I mouse (data not shown). Therefore, Brn-2 proves to serve a critical function in specification or survival of both cell types that compose the magnocellular system and one of the parvocellular cell types that comprises the central control of the pituitary-adrenal axis.

\section{Disruption of late endocrine hypothalamic develop- ment in Brn-2 (- $/-)$ mice}

On the basis of the coexpression of Brn-2 and Brn-4 in the developing and mature endocrine hypothalamus, the ontogeny of the relevant parvocellular and magnocellular cells of Brn-2 $(-1-)$ mice were evaluated by Brn-4 gene expression from E10 to p6. As shown in Figure 6, the appearance of the Brn-4 transcript and protein in cells that constitute the presumptive endocrine hypothala-

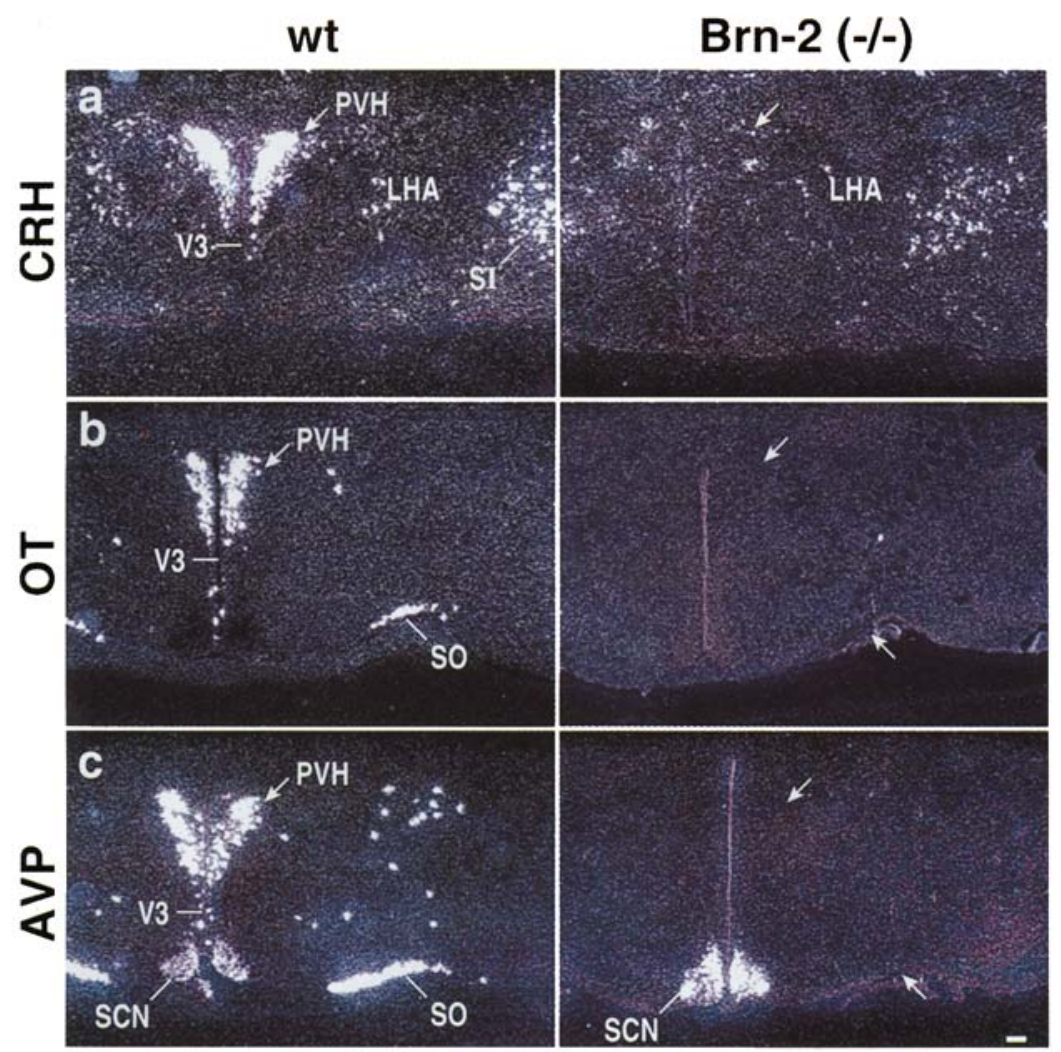

Figure 4. Failure of CRH, OT, AVP gene expression in the paraventricular and supraoptic nuclei in Brn-2 $(-1-)$ mice. $(a-c)$ Dark-field photomicrographs of in situ hybridization on coronal sections through the hypothalamus of wild-type (left $)$ and Brn-2 $(-1-)$ (right $)$ mice with $\mathrm{CRH}$, OT, and AVP cRNA; the third ventricle (V3) marks the midline. $|a|$ Robust expression of $\mathrm{CRH}$ transcripts in neurosecretory neurons of the $\mathrm{PVH}$, as well as in scattered cells in the lateral hypothalamic area (LHA) and substantia innominata $|\mathrm{SI}|$ is seen in wild-type $|\mathrm{wt}|$ mice. In Brn-2 $1-1-1$, CRH mRNA expression is retained in the latter two regions, but not in the paraventricular nucleus, which alone among these cell groups is the site of Brn-2 expression. (b) OT transcripts present in the neurosecretory neurons of the PVH and SO nuclei of wild-type mice $(b$, left $)$, are absent in both of these nuclei in $B r n-2 \mid-1-1$ mice. (c) AVP transcripts are abundant in neurosecretory neurons of the PVH and SO nuclei, and in the nonneurosecretory neurons of the suprachiasmatic nucleus $(\mathrm{SCN})$ of wild-type mice $(c$, leftl. Foci of hybridization lateral to the paraventricular nucleus are indicative of accessory neurons. No AVP transcripts were observed in the PVH and SO nuclei of Brn-2 $1-1-1$ mice. Expression of AVP in the SCN, where Brn-2 is not normally expressed, was unaffected. Bar, $50 \mu \mathrm{m}$. 


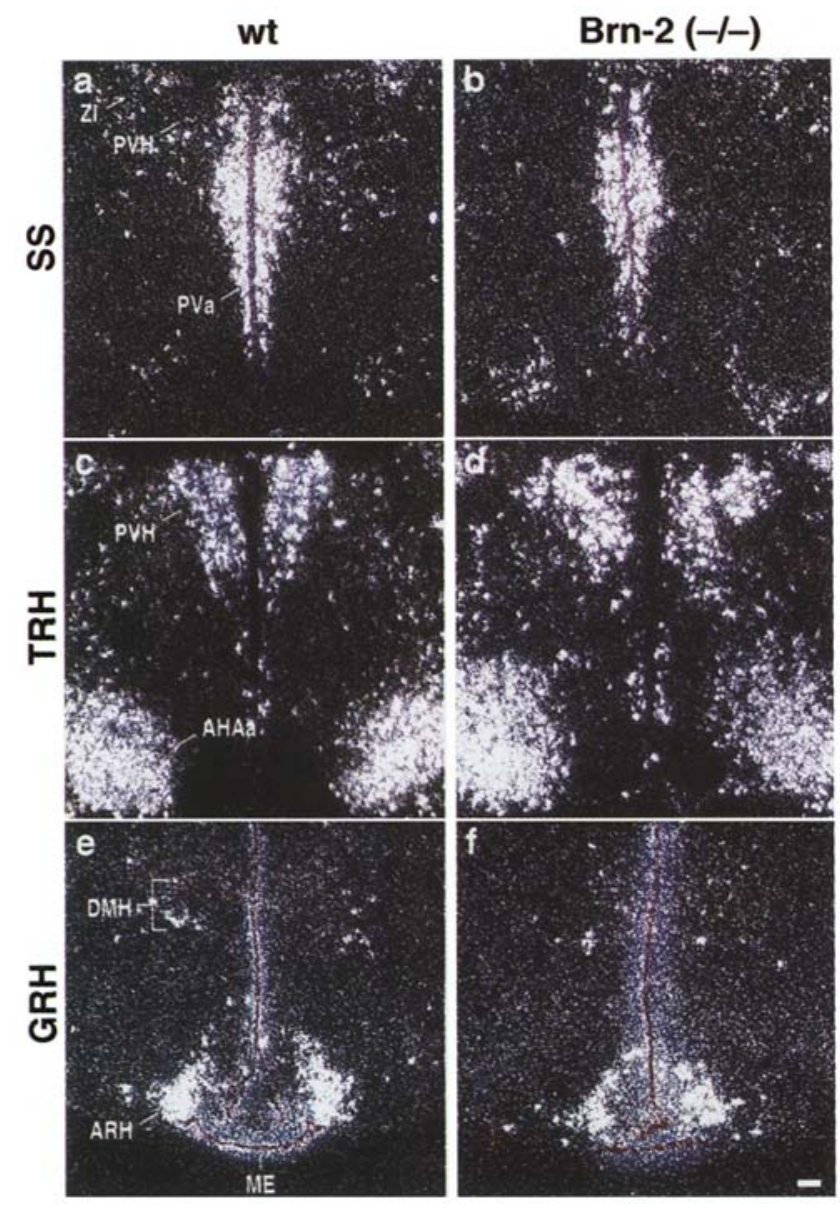

Figure 5. Somatostatin (SS), TRH, and GRH hormone gene expression remain intact in hypothalamus of wild-type and $\mathrm{Brn}-2$ $(-/-) .(a-f)$ Dark-field photomicrographs of in situ hybridization on coronal sections through the hypothalamus of wild-type $(a, c, e)$ and Brn-2 $(-1-) \mid b, d, f)$ mice with somatostatin, TRH, and GRH. $(a, b)$ Somatostatin mRNA expression in the periventricular nucleus $(\mathrm{PVa})$ of the hypothalamus and the $\mathrm{ZI}$ is unaffected in the Brn-2 $(-/-)$ mouse. (c,d) Characteristic TRH mRNA expression in the PVH nucleus and in scattered foci of TRH-positive neurons in the anterior lateral hypothalamic area (AHAa) of the hypothalamus is maintained in the Brn-2 $1-1-1$ mutant mouse (right). (e,f) GRH mRNA expression in the arcuate nucleus (ARH) at the base of the third ventricle is unaffected in the Brn-2 $1-1-1$ mouse. Scattered expression is noted in the dorsomedial hypothalamus (DMH). The median eminence $(\mathrm{ME})$ is indicated. Bar, $50 \mu \mathrm{m}$.

mus was normal in Brn-2 $|-/-|$ mice at E13. The nascent PVH and SO nuclei appeared histologically indistinguishable in wild-type and Brn-2 $(-/-)$ mice (data not shown). Together these data suggest that even in the absence of Brn-2 protein during initial developmental periods, proliferation of presumptive neuroblasts, neurogenesis, and initial migration events proceed effectively. Although, in wild-type embryos a decreased level of Brn-4 expression was observed in the nascent paraventricular region of the hypothalamus on E15-E16 (Fig. 6A; Alvarez-Bolado et al. 1995), levels of Brn-4 transcripts and protein were sufficient to follow the fate of these cells. In Brn-2 $(-1-)$ mice, there was a progressive disappearance of Brn-4-expressing cells in a dorsal to ventral fashion from E15.5 to E17 (Fig. 6; data not shown). By E16, Brn-4 gene expression in Brn-2 $1-1-1$ mice could no longer be detected in the dorsal neurons of the PVH nucleus; at E17, most ventral expression of Brn-4 in the PVH nucleus had been extinguished, and only an occasional Brn-4-positive cell remained by E19-p5 (Fig. 6).

Although CRH, OT, and AVP normally appear on E15.5-E16.5, the initial activation of these genes failed to occur in Brn-2 $(-1-)$ mice (Fig. 6; data not shown). Surprisingly, although no $\mathrm{CRH}$ transcripts could be detected in the PVH neurons in E16.5 Brn-2 $(-/-1$ mice, an occasional $\mathrm{CRH}$-expressing neuron appeared by E19.5, consistent with the finding that even in the PVH nucleus of the p $6 \mathrm{Brn}-2 \mid-1-1$ mouse, there remained a limited population of both Brn-4 and CRH-expressing cells, as assessed by immunohistochemistry using specific antisera (Fig. 6). On the basis of in situ hybridization and immunohistochemistry, Brn-2 appeared to be expressed equivalently at a cellular level from E12 through p6, whereas Brn-4 transcripts and protein were generally observed to have a biphasic expression pattern that increases from low levels of expression on E15-E16 to high, sustained levels by E19.

Histological analysis revealed a striking depletion of the cellularity of the PVH and SO nuclei, unambiguously observed by E19 (Fig. 7A; data not shown). In contrast, normal architecture was maintained in proximate structures that do not express Brn-2, such as the suprachiasmatic, anterior periventricular, and arcuate nuclei (Fig. 7A; data not shown|. These data indicate that after initial failure to activate distal target genes, most cells in these specific compartments of the endocrine hypothalamus fail to survive.

\section{Loss of the posterior pituitary in Brn-2 (-/-) mice}

Examination of the ontogeny of posterior pituitary development in Brn-2 $1-1-1$ mice revealed normal cellularity on E10-E14.5 (Fig. 7B; data not shown) and a normal complement of pituicytes /specialized astroglia of the posterior lobe) on El6, but the axonal projections that normally arrive in the presumptive posterior pituitary between E15.5 and E16.5/Galabov and Schiebler 1978) were not detected (data not shown). By E19, Brn-2 $1-/-1$ mice exhibit a complete loss of pituicytes, and the vacated posterior pituitary region comes to be occupied by an orderly infolding of the intermediate lobe as evidenced in both histological material and sections stained for proopiomelanocortin-derived peptides (Fig. 7Cl. Consistent with these observations, OT and AVP were absent in the posterior pituitary (data not shown). Therefore, Brn-2 is required for axonal projections from magnocellular neurons to invade the nascent posterior pituitary structure and these axons are required for the survival of the pituicytes of the posterior pituitary. Thinning of the median eminence was also observed /data not 
A
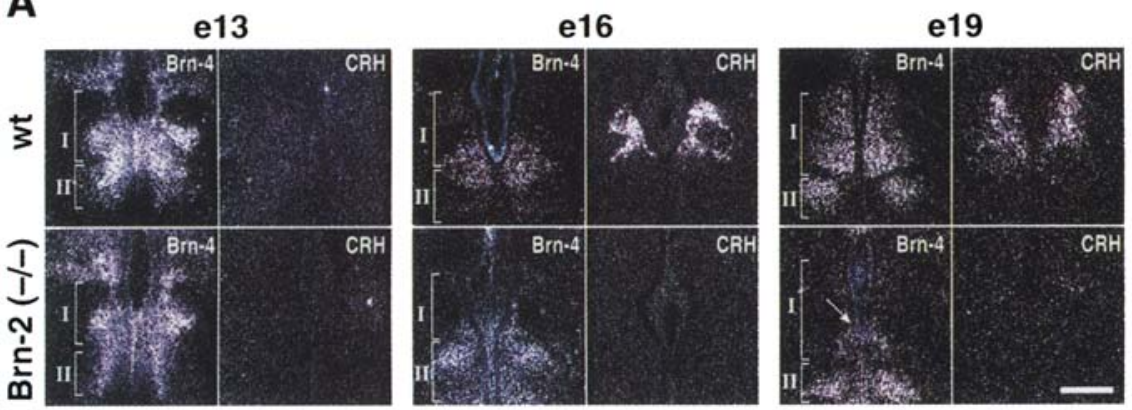

B e13

e17

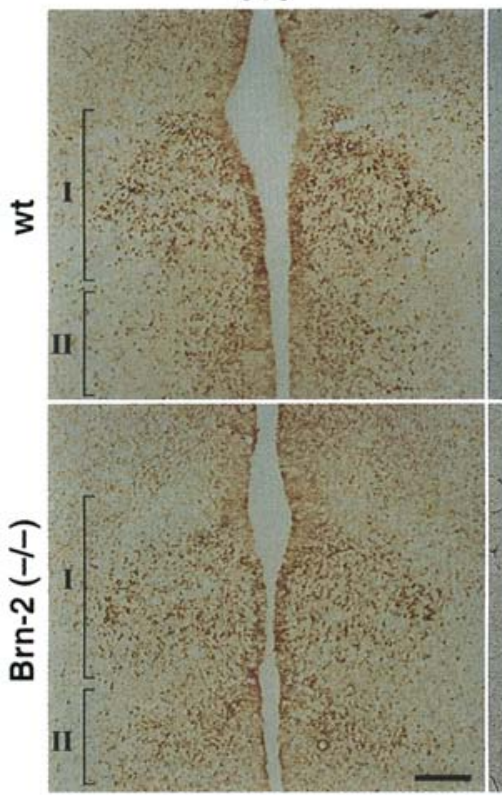

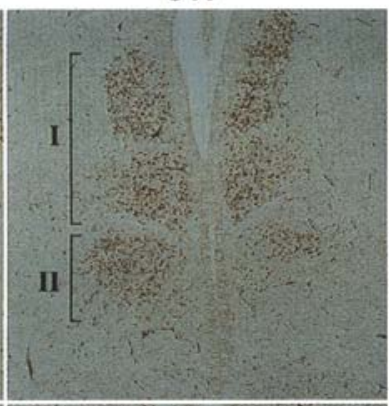

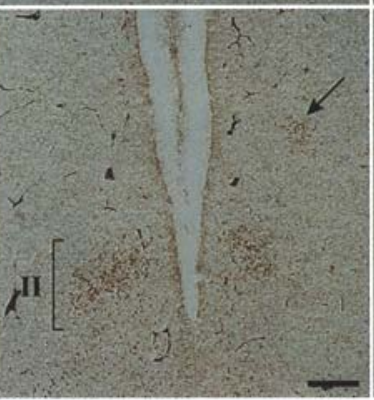

p5

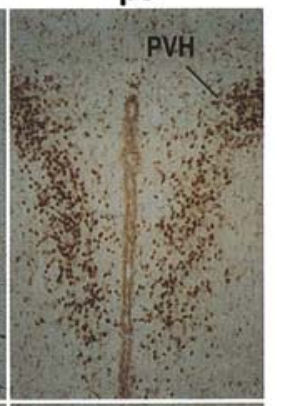

Figure 6. Ontogeny of the loss of Brn-4 and $\mathrm{CRH}$ in the PVH and SO nuclei. $(A)$ Dark-field photomicrographs of in situ hybridization analysis of Brn-4 and CRH in wild-type (top) and Brn-2(-1-) (bottom) mice at E13, E16, and E19. Brn-4 transcripts are present in two clusters (I and II) in the presumptive hypothalamus at E13; region I corresponds to nascent paraventricular neurons. At E13, the level of Brn-4 transcripts in both wild-type and $B r n-2$ $(-1-1$ animals is indistinguishable. By E16, there is a substantial decrease in the level of the Brn-4 transcript in the dorsal portion of region I and at E19 only a few Brn-4-expressing neurons are present at the ventral boundary of region I (arrow). The abundance of Brn-4 transcripts in region II is not substantially altered in the Brn-2 $(-1-)$ mouse. CRH expression in the presumptive hypothalamus initiates between E13.5 and E16; therefore, by E16 the transcript is relatively abundant. In the Brn-2 $|-|-\mid$ animal, CRH transcripts are not observed at E16 or E19. (B) A specific antiserum against $B r n-4$ was used to examine the ontogeny of $\mathrm{Brn}-4$ protein in the paraventricular hypothalamus in wildtype and Brn-2(-1-) mice. At E13, Brn-4 is present equivalently in the $\mathrm{PVH}$ neurons of wild-type and Brn-2 $(-1-)$ mice. By E17, Brn-4 protein is absent in the presumptive PVH neurons $\{\mathrm{I}\rangle$. However, a few scattered Brn-4-positive cells are observed at p5. Bar, $50 \mu \mathrm{m}$.

shown), reflecting a similar failure of axonal projections from parvocellular neurons of the PVH.

Both CRH and AVP can serve as secretagogues for adrenocorticotropic hormone $(\mathrm{ACTH}$; Plotsky 1991; Vale et al. 1981) and in Xenopus, the infundibulum is reported to be required for appearance of corticotropes (Kawamura and Kikuyama 1995). However, even with the failure of expression of both CRH and AVP in Brn-2 $1-1-1$ mice, there appears to be no defect in the appearance and maturation of any pituitary cell type. As shown in Figure $7 \mathrm{C}$, the corticotropes in the anterior lobe, as well as in the intermediate lobe, were present and contain ACTH (Fig. $7 \mathrm{C}$. All other pituitary cell types were normal (data not shown). Adrenal cortical structure and expression of the gene encoding a biosynthetic enzyme critical for glucocorticoid synthesis by the zona fasciculata, $11-\beta$-hydroxylase (Ho and Vinson 1993), were normal in Brn-2 $1-1-1$ mice (Fig. 7D). Consistent with these results, Brn-2 $1-/$ - mice had clearly measurable blood levels of corticosterone $(10-25 \mathrm{ng} / \mathrm{ml}, n=8)$ that were not significantly diminished compared to their wild-type littermates.

\section{Discussion}

Stratified expression of class III POU domain factors predict cell phenotypes in the endocrine hypothalamus

In this paper we provide data suggesting that specific hypothalamic cell phenotypes are topographically and temporally determined by a complement of class III POU domain factors expressed in a stratified fashion in the developing endocrine hypothalamus, and that a specific POU domain factor is required indispensably for the coordinate development of the neural component of the hypothalamic-pituitary axis. The highly related members of the class III POU domain factors Brn-2 and Brn-4 remain coexpressed throughout the period of proliferation, appearance of the postmitotic neurons, and subsequent terminal differentiation of parvocellular and magnocellular neurons. In contrast, more ventromedially situated nascent hypothalamic cells, which do not subserve endocrine function, express only Brn-4. Brn-1 expression becomes uniquely restricted to neurons of the presumptive zona incerta, dorsolateral to the developing paraven- 
tricular nucleus of the hypothalamus and to a columnar zone ventrolateral to the Brn-2- and Brn-4-expressing cells. Thus, the developing hypothalamus appears to contain multiple zones of cells that express specific combinations of POU domain factors, including "Brn-2 only," "Brn-4 only," "Brn-1 only," and "Brn-2 and Brn-4" cells, the boundaries of which conform to recognized regional anatomical boundaries (Fig. 8; Altman and Bayer 1986; Alvarez-Bolado et al. 1995). Furthermore, even within a zone of Brn-2- and Brn-4-positive cells, there appears to be additional stratification, with Brn-2 only cells delineating subpopulations of neurons within the PVH. For example, in the SO nucleus, Brn-2 only cells are predominantly anterodorsal, whereas Brn-2 and Brn-4 cells are predominantly posteroventral, potentially correlating with the corresponding distribution of OT- and AVP-producing neurons, respectively. A similar zone of Brn-2 only cells appear to be present in the developing PVH nucleus. Therefore, it is tempting to speculate that the combinatorial actions of class III POU domain factors specify distinct neuroendocrine phenotypes, analogous to the putative regional functions of combinations of LIM-homeo domain factors in specification of subpopulations of motor neurons, as inferred from patterns of axonal connections (Tsuchida et al. 1994; for review, see Lewin 1994). Such a model is consistent with the observation that different classes of transcription factors respect anatomical boundaries in other aspects of the developing mammalian forebrain (Rubenstein et al. 1994).

Figure 7. Loss of PVH nucleus and posterior pituitary in $B r n-2$ $(-/-)$ mice. $(A)$ Coronal sections of p5 wild-type $\mid$ left $\mid$ and Brn$2(-1-)($ right $)$ mice stained with hemotoxylin and eosin. The neuron-dense region of the $\mathrm{PVH}$ astride the dorsal aspect of the third ventricle has a marked hypocellular appearance in the Brn-2(-/ $\mid$ mouse. The neuron density of the suprachiasmatic nucleus $(\mathrm{SCN})$ at the base of the third ventricle is not affected by $B r n-2$ deletion. $|B|$ Hemotoxylin and eosin-stained sagittal sections of E13 (top) and coronal sections of E18 (bottom) wild-type and $B r n-2(-/-)$ mice at the level of the developing pituitary. At E13, development of the infundibulum (i) and anterior pituitary (AP) appears normal in Brn-2 $1-1-1$ mice. At E18, the posterior lobe of the pituitary is absent in the Brn-2 $1-1-1$ mouse (bottom right) and the region normally occupied by the posterior lobe $(\mathrm{P})$ appears to contain cells of the intermediate lobe (I). The anterior (A) and intermediate (I) lobes appear normal. $(C)$ Immunohistochemical staining of pituitaries from wild-type (left) and Brn-2 $1-/-1$ (right) mice for ACTH. The appearance of $\mathrm{ACTH}$ immunoreactive cells in the region normally occupied by the posterior lobe $\left(\mathrm{I}^{\prime}\right\rangle$ is consistent with the observation that intermediate lobe cells occupy the region vacated by the posterior lobe in $B m-2|-1-|$ mice $\left|I^{\prime}\right|$. $(D)$ In situ hybridization of an 11- $\beta$-hydroxylase cRNA probe in the adrenal glands of wild-type and $B r n \cdot 2 /-/-1$ mice. The hybridization pattern in Brn-2(-/ $)$ mice is indistinguishable from that seen in wild type. Abbreviations: $|M|$ medulla $a_{i}(Z F)$ zona fasciculata; $(Z G)$ zona glomerulosa. $|A|$ Bar, $50 \mu \mathrm{m}$; $(B \mid$ bar, $100 \mu \mathrm{m}$.

\section{Brn-2 regulates terminal hypothalamic neuronal differentiation events}

Although $B r n-2$ is expressed throughout the entire period of neurogenesis in the endocrine hypothalamus, all early developmental milestones, including initial commitment to neuronal fate, neuroblast proliferation, generation of postmitotic neurons, and lateral migration to correct loci in the nascent $\mathrm{PVH}$ and SO nuclei are maintained in the absence of Brn-2 gene expression. Thus, the critical role of $\mathrm{Brn}-2$ appears to be relatively late in the sequence of events leading to terminally differentiated

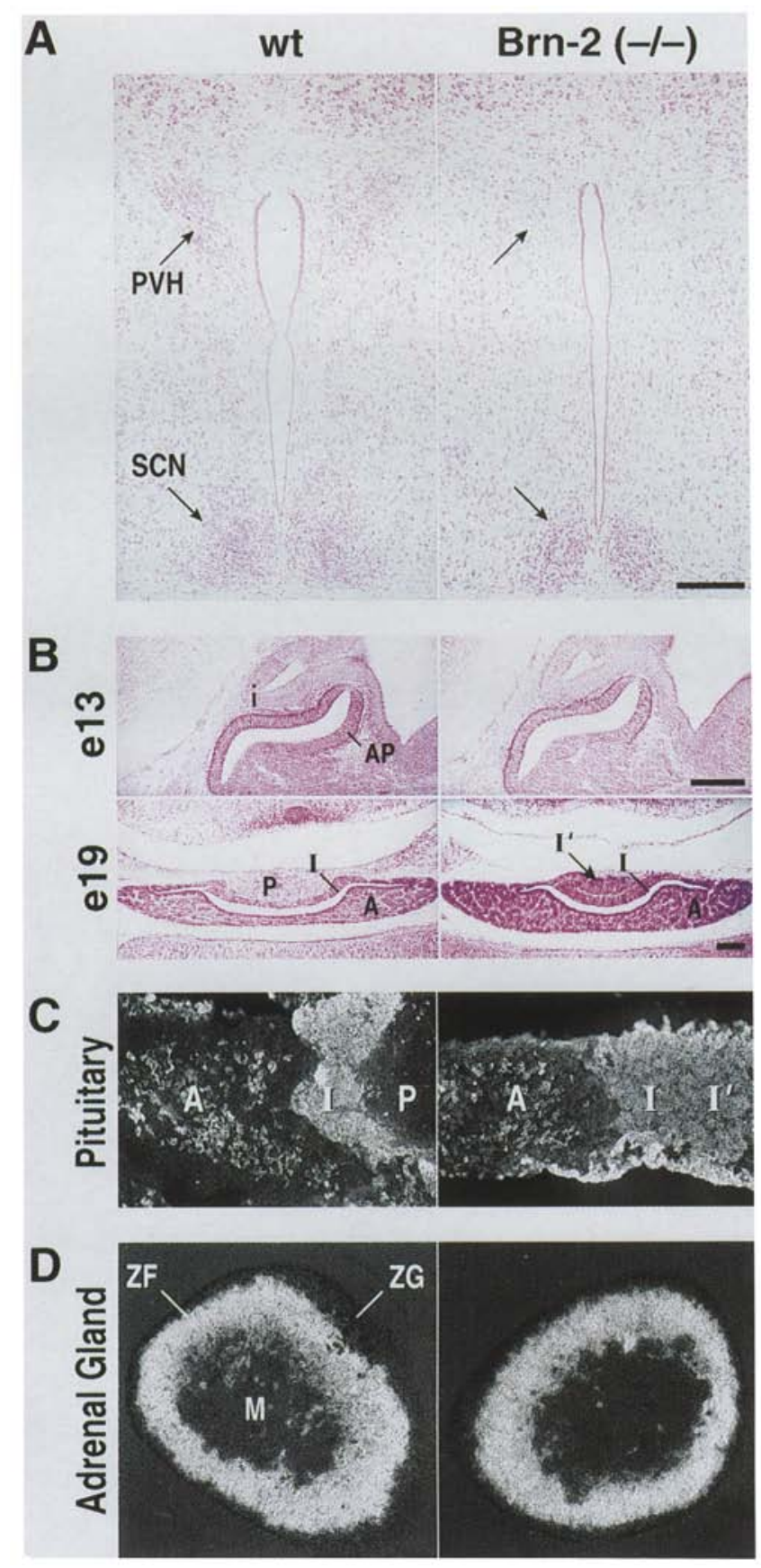




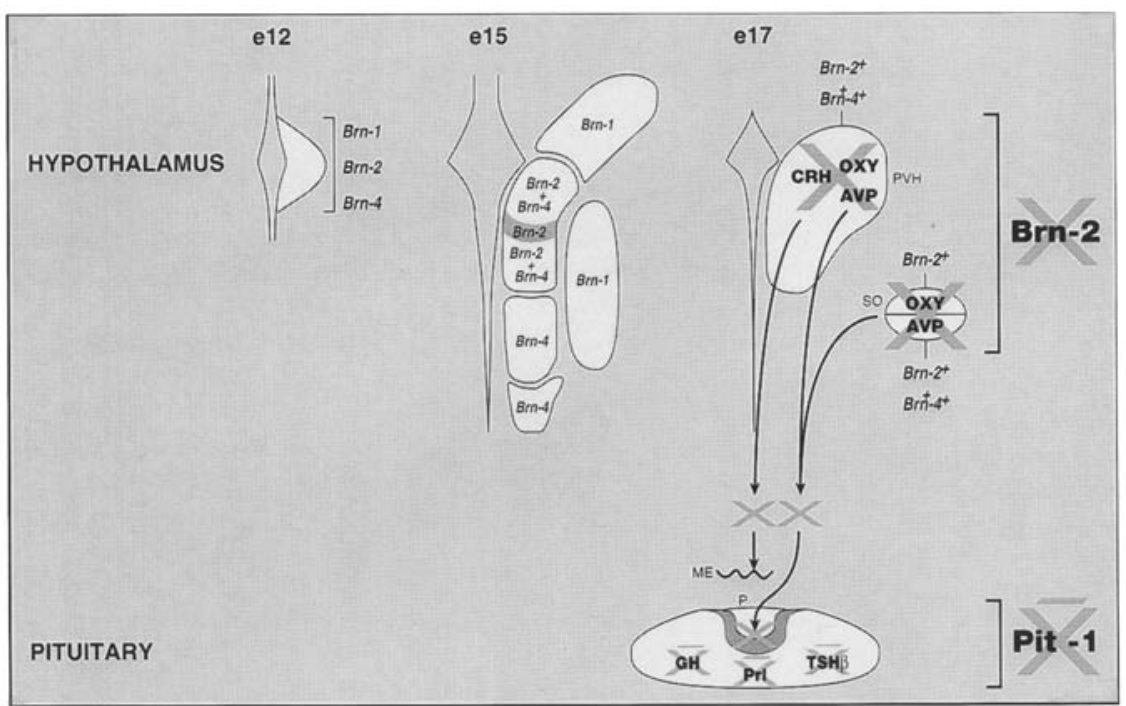

Figure 8. POU domain factors mediate coordinate development of hypothalamic-pituitary axis. Class III POU domain factors are expressed continuously from neurulation, achieving a partially overlapped pattern of expression in the nascent hypothalamus predicting patterns of neuronal diversification. The selective coexpression of Brn-2 and Brn-4 correlates with target gene expression defining neuronal cell types in the presumptive PVH and SO nuclei. Although developmental events through E14-E15 do not require Brn-2, terminal differentiation of specific parvocellular and magnocellular cell types fails in the absence of Brn-2. Thus, there is a failure of initial activation of CRH, AVP, and OT genes, proper axonal connections to the median eminence $(\mathrm{ME})$ or posterior pituitary, and survival of neurons of the paraventricular and supraoptic nucleus. Progressive disappearance of these neurons occurs in a temporal gradient and proceeds in a dorsal-ventral fashion. These functional effects of Brn-2, therefore, prove to be temporally coincident with the role of Pit-1 in three anterior pituitary cell types, including somatotrophs, which produce growth hormone $|\mathrm{GH}|$, lactotrophs, which produce prolactin (Prl), and thyrotrophs, which produce thyrotrope-stimulating hormone (TSH $\beta)$.

neuronal phenotypes, including activation of neuropeptide gene expression, axonal outgrowth, and maintenance of neuronal viability, all of which fail to occur in the absence of Brn-2. Before axonal invasion (Galabov and Scheibler 1978), development of the posterior pituitary gland proceeds normally in the Brn-2(-1-) mice. However, pituicytes subsequently disappear and there is complete loss of the posterior pituitary, suggesting that the magnocellular axons elaborate tropic factors required for maintenance of the posterior pituitary pituicytes. Finally, there is progressive loss of the parvocellular and magnocellular neurons of the PVH and SO nuclei, proceeding in a clear dorsal-ventral pattern, commencing on E15-E16, with loss of most cells by E17.

These data indicate that the selective actions of Brn-2 are essential for terminal differentiation and survival of both magnocellular neurosecretory cell types and of parvocellular neurosecretory neurons that express CRH specifically. Phenotypic specification of the parvocellular cell types that govern pituitary growth hormone and thyrotropin secretion progresses in an essentially normal manner in Brn-2 $(-/-)$ mice. Intriguingly, our data also indicate that rare cells in the hypothalamus of $B r n-2 \mid-1$ - | mice stochastically escape the consequence of a lack of functional Brn-2 protein, and are capable of subsequently expressing terminal target genes. We speculate that the precise timing at which $B r n-2$ gene deletion exerts its effect may, in part, reflect the temporal aspects of progressively increasing $\mathrm{Brn}-4$ gene expression in the affected cell types. These results indicate a role for Brn-2 distal to reported neuralizing effects for both $B r n-2$ and Brn-4 homologs (Fujii and Hamada 1993; Witta et al. 1995). Humans who may harbor mutations in their Brn-4 gene are reported to exhibit only nonsyndromic X-linked deafness (de Kok et al. 1995). Because all sequential early developmental milestones are maintained in the absence of $B r n-2$ gene expression, and the critical role of $\mathrm{Brn}-2$ is relatively late in the sequence of events leading to terminal differentiation and survival of neuronal phenotypes, it is conceivable that Brn-4 is functionally redundant with Brn-2 during the initial phases of neurogenesis.

These actions of Brn-2 are in concert with those of the POU domain factors that have been investigated genetically in other organ systems or species, where their roles also seem to involve modulation of late developmental decisions, including Pit-1 ( $\mathrm{Li}$ et al. 1990), unc-86 (Finney and Ruvkun 1990), Oct-2 (Corcoran et al. 1993), and pdm1, pdm2/miti-mere, and drifter genes in Drosophila (Yang et al. 1993; Anderson et al. 1995; Bhat et al. 1995; Yeo et al. 1995). In the case of the Brn-2-induced loss of the endocrine hypothalamus, there were no developmental consequences in the downstream levels of the hypothalamic-pituitary-adrenal axis; similar to the minimal consequences observed with $C R H$ gene deletion (Mugila et al. 1995) or defects in AVP (Schmale and Richter 1984). We can only speculate that the nonviability of the Brn-2-gene deleted mouse reflects the more severe physiological demands imposed by the simultaneous loss of three cell types in the endocrine hypothalamus.

\section{POU domain factors mediate the coordinate development of the hypothalamic-pituitary axis}

The precise patterns and timing of coordinate development of the hypothalamic-pituitary axis implies a synchronization of regulatory events, and we suggest that this, in part, involves the parallel actions of one family of 
determining factors. In the case of the anterior pituitary gland, initial expression of $\mathrm{Pit}-1$ coincides with initiation of terminal differentiation events in three cell types. Pit-1 is also required for proliferation/survival of these three cell types (Fig. 8) by regulation of specific tropic factor receptors (Li et al. 1990; Godfrey et al. 1993; Lin et al. 1993). Although the expression of POU III factors in the hypothalamus begins at a much earlier stage of development than is the case for Pit-1, the developmental defects of $B r n-2$ gene deletion are restricted to a temporal window virtually identical to that at which Pit-1 exerts its critical actions (Fig. 8). Brn-2, like Pit-1, is required for both activation of terminal target genes and cellular survival (see Fig. 8). Thus, POU domain factor-dependent terminal differentiation and cell survival events, in generation of the hypothalamic-pituitary axis, may be prototypic of development of other organ systems generated from cells of distinct embryonic origins.

\section{Materials and methods \\ Construction of Brn-2-targeting vector and generation germ-line-transmitting mice}

A mouse Brn-2 genomic clone was isolated from a J1 129/Sv mouse genomic library (Stratagene $\lambda$ Fix II vector) using the rat Brn-2 POU domain sequence. The 5 '-flanking region comprising a 4.5-kb NotI-EcoRI fragment and a 7.5-kb EcoRI 3' flanking fragment were subcloned into the corresponding cloning sites of the neomycin-containing vector pBM2.0, where expression of the neomycin gene is driven by the mouse phosphoglycerate kinase (PGK) promoter. The final vector for use during the electroporation experiment was created by subcloning into a herpes simplex virus thymidine kinase (2HSV-TK) plasmid, which resulted in the positioning of TK genes at both ends of the homologous Brn-2-flanking DNA regions. Upon correct targeting the entire Brn-2-coding region and $2.5 \mathrm{~kb}$ of the $5^{\prime}$ promoter/ enhancer region is replaced with the pgk-neomycin (neo) gene. The J1 ES cell line (Li et al. 1992) was cultured on mitomycin C-treated neo-resistant mouse embryonic fibroblasts (Robertson 1987) and grown in the presence of DMEM high glucose media containing $15 \%$ FCS (Hyclone) and supplemented with exogenously added leukemia inhibitory factor (LIF) (ESGRO, GIBCO Bethesda Research Laboratories|. Targeting vector DNA was linearized $(25 \mu \mathrm{g})$ and electroporated into $2 \times 10^{7} \mathrm{ES}$ cells in $0.8 \mathrm{ml}$ of electroporation buffer (Li et al. 1992) at $250 \mathrm{~V}$ and 500 $\mu \mathrm{F}$ using a Genepulser (Bio-Rad). Cells were grown for 7-9 days in $250 \mu \mathrm{g} / \mathrm{ml} \mathrm{G} 418$ and $2 \mathrm{~mm}$ gancyclovir (Syntex) and 233 double drug-selected clones were grown for an additional 3 days. Clones were frozen and their genomic DNA isolated for Southern blot analysis.

Cell lines that had undergone homologous recombination were identified using the $3^{\prime}$ external probe that hybridizes to a 20-kb EcoRI fragment at the wild-type Brn-2 locus and a 15-kb EcoRI fragment at the Brn-2 $(-/-)$ allele. A neo probe $(0.5-\mathrm{kb}$ fragment containing the $\mathrm{pgk}$ poly $(\mathrm{A})$ sequencel, which recognizes a 4.5-kb BamHI fragment in the Brn-2 $1-/-1$ allele, was used to identify homologous recombination in the $5^{\prime}$ flanking region. This $0.5-\mathrm{kb}$ internal probe also hybridizes to a $4-\mathrm{kb}$ $B a m H I$ fragment that corresponds to the endogenous murine pgk gene.

ES cell line 33, which met the requirement for homologous recombination at the $\mathrm{Brn}-2$ locus, was microinjected into $\mathrm{C} 57 \mathrm{BL} / 6$ blastocysts that were then transferred to pseudopreg- nant females. Chimeric male mice were backcrossed to C57BL/ 6 females and germ-line transmission was scored by the presence of the agouti coat color. Heterozygotes were identified by Southern hybridization and PCR analysis. The Brn-2 primers used in the PCR reaction, 5'-CACCCAGGCGCGCACCACGACCCG-3' and 5'-CGGCGCCCGGCAGAGTCCCTCCTC3 ', produce a $0.5-\mathrm{kb}$ band encompassing the mouse Brn-2 POU domain. The primers used to PCR the neor gene, 5'-CCACACCCAGCCGGCCACAGTCGATGA-3' and 5'-AGAGGCTATTCGGCTATGACTGGGCA-3', yield a 0.6 -kb fragment. The final PCR reaction conditions contain $1 \times$ PCR buffer, $2.5 \mathrm{~mm}$ $\mathrm{MgCl}_{2}, 0.6 \mathrm{~mm}$ each of dNTP, 5\% DMSO, and $20 \mathrm{ng}$ of each primer. Less than $250 \mathrm{ng}$ of genomic DNA was used for each PCR reaction.

\section{Phenotype analysis}

Heterozygous matings were set up and the embryos were allowed to come to term, after which the animals were prepared for analysis just before the anticipated time of death. Postnatal animals were anesthetized, tails and/or hind limbs removed for PCR genotyping analysis, and cardiac perfusion was performed with PBS followed by $10 \%$ formalin. To establish timed matings between heterozygous mice, the vaginal plug was monitored and considered to be E0.5. In addition, the length between the crown and rump was measured allowing for an approximate confirmation of the developmental stage of the embryo. Before E17, embryos were fixed by submersion in $10 \%$ formalin; postE17 embryos were subjected to cardiac perfusion and fixation.

\section{Histology}

For paraffin sections, animal tissues were collected as outlined above, except that they were perfused with Bouin's fixative 175 $\mathrm{ml}$ of saturated picric acid, $25 \mathrm{ml}$ of formalin, $5 \mathrm{ml}$ of acetic acid, and $0.9 \mathrm{~g}$ of $\mathrm{NaCl}$ ). The tissues were washed in several volumes of PBS, paraffin embedded and sectioned on a microtome, and stained with cresyl violet acetate, Nissl, or hemotoxylin and eosin.

\section{In situ hybridization}

In situ hybridizations were carried out as described by Simmons et al. $|1989|$. Overnight hybridizations were performed with ${ }^{35} \mathrm{~S}$ labeled antisense riboprobes $11 \times 10^{7} \mathrm{cpm} / \mathrm{ml}$ hybridization bufferl at $60^{\circ} \mathrm{C}$. The antisense riboprobes from the following genes were used during our analysis of the Brn-2 knockout phenotype: rat $\mathrm{CRH}$, rat TRH, rat AVP, rat OT, rat GRH, mouse growth hormone, mouse thyrotroph-stimulating hormone, mouse pro-opiomelanocortin hormone, 11- $\beta$-hydroxylase (Ho and Vinson 19931, rat somatostatin, and mouse Brn-4.

For whole mount in situ hybridization, mouse embryos were collected and extraembryonic membranes were removed. Embryos were fixed overnight at room temperature in $10 \%$ buffered formalin, rinsed several times with $70 \%$ ethanol, and then stored at $-20^{\circ} \mathrm{C}$ in $70 \%$ ethanol. Whole mount in situ hybridization was performed essentially as describe by Wilkinson (1993). The reaction was stopped by washing twice for $10 \mathrm{~min}$ in TE [10 mM Tris (pH 8.0), 1 mM EDTA]. Embryos were stored in $10 \%$ buffered formalin in the dark. Before photography embryos were rinsed in TE.

\section{Immunohistochemical analysis}

Guinea pig and/or rabbit polyclonal antibodies were raised against the amino termini of the Brn-1 (amino acids 87-313), 
Brn-2 (amino acids 1-249), and Brn-4 (amino acids 1-172) proteins. Animals were immunized with a combination of glutathionine $S$-transferase (GST) fusion and His-tagged proteins, which were expressed in Escherichia coli and partially purified over glutathione agarose (Sigma) or $\mathrm{Ni}^{2+}-\mathrm{NTA}$-agarose /Qiagen| affinity columns. The primary antibodies used were $2 \mathrm{~GB}$ guinea pig anti-Brn-2 used at 1:1000; 1G2 guinea pig anti-Brn-1 used at 1:500; and, 4R3 rabbit anti-Brn-4 used at 1:500. Specificity of the antibodies was confirmed by Western analysis and gel mobility-shift assays with bacterially expressed or in vitrotranslated proteins.

Immunohistochemical detection was performed using freefloating $(20-40 \mu \mathrm{m})$ or slide-mounted $(10-20 \mu \mathrm{m})$ cryostat sections. Briefly, free-floating sections were collected in nets, washed in $\mathrm{Na}-\mathrm{PBS}$, incubated for $10 \mathrm{~min}$ in $0.3 \% \mathrm{H}_{2} \mathrm{O}_{2}, \mathrm{Na}-$ PBS, washed twice in Na-PBS and then incubated with the primary antibody overnight at $4^{\circ} \mathrm{C}$ in $\mathrm{Na}-\mathrm{PBS}$ containing $5 \%$ normal goat serum and $0.3 \%$ Triton X-100 (20-30 sections $/ \mathrm{ml}$. Sections were washed in Na-PBS and primary antibody was detected using the appropriate anti-rabbit or anti-guinea pig Vectastain $\mathrm{ABC}$ kit (Vector) followed by reaction with diaminobenzidine in the presence of hydrogen peroxide. Alternatively rhodamine-conjugated anti-rabbit IgG $(\mathrm{Fab}$ fragment; Boehringer Mannheim) or fluorescein-conjugated anti-guinea pig IgG (Cappel) were used to detect primary antibody. In cases where the primary antibody was detected with a fluorescent secondary antibody, sections were mounted onto Superfrost Plus slides (Fisher) using SlowFade Antifade reagents (Molecular Probes, Inc.).

Embryonic cryostat sections were mounted on poly-lysine subbed slides and incubated immediately in Na-PBS. Incubation with primary antibodies and detection with secondary antibodies was as described for free-floating brain sections.

When immunohistochemical staining was used in combination with in situ hybridization the immunohistochemical staining with the $2 \mathrm{~GB}$ Brn-2 antibody was performed essentially as described above with the following exceptions: $5 \mathrm{mg} / \mathrm{ml}$ of heparin and $2 \%$ BSA, rather than $5 \%$ normal goat serum, were used in the first antibody incubation, and two rounds of incubation with the biotinylated second antibody followed by incubation with the $A B C$ complex were performed. In situ hybridization was performed as above except that two rounds of hybridization with the antisense probe were done with a brief rinsing of the sections with $2 \times \mathrm{SSC}, 1 \mathrm{~mm}$ DTT in between. The final $0.1 \times$ $\mathrm{SSC}$ was done at $75^{\circ} \mathrm{C}$.

\section{Cotransfection assays}

Expression plasmid $(1 \mu \mathrm{g})$ and reporter plasmid $\{1 \mu \mathrm{g})$ were cotransfected into CV-1 cells by the calcium-phosphate precipitation method. Cells were harvested $48 \mathrm{hr}$ after transfection and luciferase assays were performed as described by Ingraham et al. (1988). Brn-2 and Brn-4 expression vectors contain the full-length cDNA inserted into the cytomegalovirus (CMV) expression vector. Reporter constructs contain the CRH promoter, the tyrosine hydroxylase promoter (TH promoter), three copies of a high-affinity Brn-2 binding site $13 \times$ CRHII-luciferase; Li et al. 1993), or three copies of an estrogen response element $(3 \times$ ERE) cloned upstream of a luciferase reporter. $3 \times$ CRHII and $3 \times$ ERE also contain nucleotides -36 to +25 of the prolactin promoter.

\section{Acknowledgments}

We thank Farideh Hooshmand, Mary Ayers, and Adam Uribe for their invaluable assistance in development of the founder mice;
Bogi Andersen, John Bermingham, and Mathias Treier for critical reading of this manuscript; Michael Wegner and Simon Rhodes for the gift of anti-Tst-1 sera; Larry Swanson for probes and antisera; Cynthia Mellon for the 11- $\beta$-hydroxylase probe; $D$. Richter for OT and vasopressin probes; and the laboratory of Soon Lee for assistance with corticosterone assays. We gratefully acknowledge Peggy Myer for her expertise and generous assistance in preparation of illustrations and Beth Stawiarski in preparation of this manuscript. This research was supported by grants from National Institutes of Health (NIH) to P.E.S and M.G.R. A.K.R. is a recipient of an NRSA from the NIH. P.E.S. is an Investigator of the Foundation for Medical Research. M.G.R. is an Investigator with the Howard Hughes Medical Institute.

The publication costs of this article were defrayed in part by payment of page charges. This article must therefore be hereby marked "advertisement" in accordance with 18 USC section 1734 solely to indicate this fact.

\section{References}

Altman, J. and S.A. Bayer. 1986. The development of the rat hypothalamus. In Advances in anatomy, embryology and cell biology (ed. F. Beck, W. Hild, W. Kriz, R. Ortman, J.E. Pauly, and T.H. Schiebler), Vol. 1600, pp. 1-178. SpringerVerlag, Berlin, Germany.

Alvarez-Bolado, G., M.G. Rosenfeld, and L.W. Swanson. 1995. Model of forebrain regionalization based on spatiotemporal patterns of POU-III homeobox gene expression, birthdates, and morphological features. I. Comp. Neurol. 355: 237-295.

Andersen, B. and M.G. Rosenfeld. 1995. Pit-1 determines cell types during development of the anterior pituitary gland. $I$. Biol. Chem. 269: 29335-29338.

Anderson, M.G., G.L. Perkins, P. Chittick, R.J. Shrigley, and W.A. Johnson. 1995. drifter, a Drosophila POU domain transcription factor, is required for correct differentiation and migration of tracheal cells and midline glia. Genes \& Dev. 9: $123-137$.

Assa-Munt, N., R.J. Mortishire-Smith, R. Aurora, W. Herr, and P.E. Wright. 1993. The solution structure of the Oct-1 POU specific domain reveals a striking similarity to the bacteriophage repressor DNA binding domain. Cell 73: 193-205.

Bhat, K.M., S.J. Poole, and P. Schedl. 1995. The miti-mere and pdml genes collaborate during specification of the RP2/sib lineage in Drosophila neurogenesis. Mol. Cell. Biol. 15: 4052-4063.

Bodner, M., J.L. Castrillo, L.E. Theill, T. Deerinck, M. Ellisman, and $M$. Karin. 1988. The pituitary specific transcription factor GHF-1 is a homeobox containing protein. Cell 50: 267275.

Boncinelli, E., M. Gulisano, and V. Broccoli. 1993. Emx and Otx homeobox genes in the developing mouse brain. I. Neurobiol. 24: 1356-1366.

Bulfone, A., L. Puelles, M.H. Porteus, M.A. Frohman, G.R. Martin, and J.L. Rubenstein. 1993. Spatially restricted expression of Dlx-1, Dlx-2 (Tes-1), Gbx-2, and Wnt-3 in the embryonic day 12.5 mouse forebrain defines potential transverse and longitudinal segmental boundaries. 7 . Neurosci. 13: 31553172 .

Chalepakis, G., A. Stoykova, J. Wiinholds, P. Tremblay, and P. Gruss. 1993. Pax: Gene regulators in the developing nervous system. I. Neurobiol. 24: 1367-1384.

Clerc, R.G., L.M. Corcoran, J.H. Lebowitz, D. Baltimore, and P.A. Sharp. 1988. The B-cell specific Oct-2 protein contains POU box- and homeo-box type domains. Genes \& Dev. 
2: $1570-1581$.

Corcoran, L.M., M. Karvelas, G.J.V. Nossal, Z.S. Ye, T. Jacks, and D. Baltimore. 1993. Oct-2, although not required for early B-cell development, is critical for later B-cell maturation and for postnatal survival. Genes \& Dev. 7: 570-582.

Cunningham, E.T. Jr. and P.E. Sawchenko. 1991. Reflex control of magnocellular vasopressin and oxytocin secretion. Trends Neurosci. 14: 406-411.

de Kok, Y.J., S.M. van der Maarel, M. Bitner-Glindzicz, 1. Huber, A.P. Monaco, S. Malcolm, M. E. Pembrey, H.H. Ropers, and F.P. Cremers. 1995. Association between X-linked mixed deafness and mutations in the POU domain gene POU3F4. Science 267: 685-688.

Dekker, N., M. Cox, R. Boelens, C.P. Verrijzer, P.C. van der Vliet, and R. Kaptein. 1993. Solution structure of the POUspecific DNA-binding domain of Oct-1. Nature 362: 852855.

Dolle, P., V. Fraulob, P. Kastner, and P. Chambon. 1994. Developmental expression of murine retinoid $X$ receptor $(R X R)$ genes. Mech. Dev. 45: 91-104.

Eagleson, G.W. and W.A. Harris. 1990. Mapping of the presumptive brain regions in the neural plate of Xenopus laevis. $I$. Neurobiol. 21: 427-440.

Finney, M. and G. Ruvkun. 1990. The unc- 86 gene product couples cell lineage and cell identity in C. elegans. Cell 63: 895905.

Finney, M., G. Ruvkun, and H.R. Horvitz. 1988. The C. elegans cell lineage and differentiation gene unc- 86 encodes a protein containing a homeodomain and extended sequence similarity to mammalian transcription factors. Cell 55: 757769.

Fujii, H. and H. Hamada. 1993. A CNS-specific POU transcription factor, Brn-2, is required for establishing mammalian neural cell lineages. Neuron 11: 1197-1206.

Galabov, P. and T.H. Scheibler. 1978. The ultrastructure of the developing neural lobe. Cell Tiss. Res. 189: 313-329.

Godfrey, P., J.O. Rahal, W.G. Beamer, N.G. Copeland, N.A. Jenkins, and K.E. Mayo. 1993. GHRH receptor of little micc contains a missense mutation in the extracellular domain that disrupts receptor function. Nature Genet. 4: 227-232.

Grino, M., W.S. Young III, and J.M. Burgunder. 1989. Ontogeny of expression of the corticotropin-releasing factor gene in the hypothalamic paraventricular nucleus and of the proopiomelanocortin gene in rat pituitary. Endocrinology 124: 6068.

Guillemin, R., P. Brazeau, P. Bohlen, F. Esch, N. Ling, and W.B. Wehrenberg. 1982. Growth hormone-releasing factor from a human pancreatic tumor that caused acromegaly. Science 218: $585-587$.

Hara, Y., A.C. Rovescalli, Y. Kim, and M. Nirenberg. 1992. Structure and evolution of four POU domain genes expressed in mouse brain. Proc. Natl. Acad. Sci. 89:32803284

He, X., M.N. Treacy, D.M. Simmons, H.A. Ingraham, L.W. Swanson, and M.G. Rosenfeld. 1989. Expression of a large family of POU-domain regulatory genes in mammalian brain development. Nature 340: 35-42.

Herr, W. and M.A. Cleary. 1995. The POU domain: Versatility in transcriptional regulation by a flexible two-in-one DNAbinding domain. Genes \& Dev. 9: 1679-1693.

Herr, W., R.A. Sturm, R.G. Clerc, L.M. Corcoran, D. Baltimore, P.A. Sharp, H.A. Ingraham, M.G. Rosenfeld, M. Finney, G. Ruvkun, and H.R. Horvitz. 1988. The POU domain: A large conserved region in the mammalian Pit-1, Oct-1, Oct-2, and Caenorhabditis elegans unc-86 gene products. Genes \& Dev. 2: 1513-1516.
Ho, M.M. and G.P. Vinson. 1993. 11- $\beta$-hydroxylase gene expression in the rat adrenal cortex. I. Endocrinol. 139: 301-306.

Ingraham, H.A., R. Chen, H.J. Mangalam, H. Elsholtz, S.E. Flynn, C.R. Lin, D.M. Simmons, L.W. Swanson, and M.G. Rosenfeld. 1988. A tissue-specific transcription factor containing a homeodomain specifies a pituitary phenotype. Cell 55: 519-529.

Kawamura, K. and S. Kikuyama. 1995. Induction from posterior hypothalamus is essential for the development of the pituitary proopiomelanocortin (POMC) cells of the toad (Bufo iaponicusl. Cell Tiss. Res. 279: 223-239.

Klemm, J.D., M.A. Rould, R. Aurora, W. Herr, and C.O. Pabo. 1994. Crystal structure of the Oct-1 POU domain bound to an octamer site: DNA recognition with tethered DNA-binding modules. Cell 77: 21-32.

Ko, H.S., P. Fast, W. McBride, and L.M. Staudt. 1988. A human protein specific for the immunoglobulin octamer DNA motif contains a functional homeodomain. Cell 55: 135-144.

Lai, E., K.L. Clark, S.K. Burley, and J.E. Darnell Jr. 1993. Hepatocyte nuclear factor $3 /$ forkhead or "winged helix" proteins: A family of transcription factors of diverse biologic function. Proc. Natl. Acad. Sci. 90: 10421-10423.

Lee, J.E., S.M. Hollenberg, L. Snider, D.L. Turner, N. Lipnick, and $\mathrm{H}$. Weintraub. 1995. Conversion of Xenopus ectorderm into neurons by NeuroD, a basic helix-loop-helix protein. Science 268: 836-844.

Le Moine, C. and W.S. Young III. 1992. RHS2, a POU domaincontaining gene, and its expression in developing and adult rat. Proc. Natl. Acad. Sci. 89: 3285-3289.

Lewin, B. 1994. On neuronal specificity and the molecular basis of perception. Cell 79: 935-943.

Li, E., T.H. Bestor, and R. Jaenisch. 1992. Targeted mutation of the DNA methyltransferase gene results in embryonic lethality. Cell 69: 915-926.

Li, P., X. He, M.R. Gerrero, M. Mok, A. Aggarwal, and M.G. Rosenfeld. 1993. Spacing and orientation of bipartite DNAbinding motifs as potential functional determinants for POU domain factors. Genes \& Dev. 7: 2483-2496

Li, S., E.B. Crenshaw III, E.J. Rawson, D.M. Simmons, L.W. Swanson, and M.G. Rosenfeld. 1990. Dwarf locus mutants lacking three pituitary cell types result from mutations in the POU-domain gene pit-1. Nature 34: 528-533.

Lin, C., S. Lin, C. Chang, and M.G. Rosenfeld. 1992. Pit-1 dependent expression of the receptor for growth hormone-releasing factor mediates pituitary cell growth. Nature 360: $765-768$.

Lin, S., C.R. Lin, I. Gukovsky, A.J. Lusis, P.E. Sawchenko, and M.G. Rosenfeld. 1993. Molecular basis of the little mouse phenotype and implications for cell type-specific growth. Nature 364: 208-213.

Mathis, J.M., D.M. Simmons, X. He, L.W. Swanson, and M.G. Rosenteld. 1992. Brain 4: A novel mammalian POU domain transcription factor exhibiting restricted brain-specific expression. EMBO /. 11: 2551-2561.

Meister, B. 1993. Gene expression and chemical diversity in hypothalamic neurosecretory neurons. Mol. Neurobiol. 7: $87-110$.

Monuki, E.S., R. Kuhn, G. Weinmaster, B. Trapp, and G. Lemke. 1990. Expression and activity of the POU transcription factor SCIP. Science 249: 1300-1303.

Mugila, L., L. Jacobson, P. Dikkes, and J.A. Majzoub. 1995. Corticotropin-releasing hormone deficiency reveals major fetal but not adult glucocorticoid need. Nature 373: 427-432.

Müller, M., S. Ruppert, W. Schaggner, and P. Matthias. 1988. A cloned octamer transcription factor stimulates transcription from lymphoid specific promoters in non-B cells. Nature 
336: $544-551$.

Parks, J.S., E.I. Kinoshita, and R.W. Pfäffle. 1993. Pit-1 and hypopituitarism. Trends Endocrinol. Metab. 4: 81-85.

Plotsky, P.M. 1991. Pathways to the secretion of adrenocorticotropin: A view from the portal. I. Neuroendocrinol. 3: 1-9.

Price, M. 1993. Members of the Dlx- and NKx-2-gene families are regionally expressed in the developing forebrain. I. Neurobiol. 24: 1385-1399.

Robertson, E.J. 1987. Embryo-derived stem cell lines. In Teratocarcinomas and embryonic stem cell: A practical ap. proach (ed. E.J. Robertson), pp. 71-112. IRL Press, Oxford, UK.

Rubenstein, I.L.R., S. Martinez, K. Shimamura, and L. Puelles. 1994. The embryonic vertebrate forebrain: The prosomeric model. Science 266: 578-580.

Sawchenko, P.E., T. Imaki, and W. Vale. 1992. Colocalization of neuroactive substances in the endocrine hypothalamus. Functional anatomy of the neuroendocrine hypothalamus. CIBA Found. Symp. 168: 16-42.

Scheidereit, C., J.A. Cromlish, T. Gerster, K. Kawakami, C.G. Balmaceda, R.A. Currie, and R.G. Roeder. 1988. A human lymphoid-specific transcription factor that activates immunoglobulin genes in a homeobox protein. Nature 336: $552-$ 557.

Schmale, H. and D. Richter. 1984. Single base deletion in the vasopressin gene is the cause of diabetes insipidous in Brattleboro rats. Nature 308: 705-709.

Simmons, D.M., J.L. Arriza, and J.W. Swanson. 1989. A complete protocol for in situ hybridization of messenger RNAs in brain and other tissues with radiolabeled single stranded RNA probes. I. Histotechnol. 12: 169-181.

Sturm, R.A., G. Das, and W. Herr. 1988. The ubiquitous octamer binding protein Oct-1 contains a POU domain with a homeo box subdomain. Genes \& Dev. 2: 1582-1599.

Suzuki, N., H. Rohdewohld, T. Neuman, P. Gruss, and H.R. Scholer. 1990. Oct-6: A POU transcription factor expressed in embryonal stem cells and in the developing brain. EMBO I. 9: 3723-3732.

Swanson, L.W. 1986. Organization of mammalian neuroendocrine system. In Handbook of physiology, Sect. 1. The nervous system, Vol. IV, Intrinsic regulatory systems of the brain (ed. V.B. Mountcastle, Floyd E. Bloom, and S.R. Geigerl, pp. 317-363. American Physiological Society, Bethesda, MD.

- 1987. The hypothalamus. In Handbook of chemical neuroanatomy, Part I led. A Bjorklun, T. Hokfelt, and L.W. Swanson|, pp. 1-124. Elsevier Publishing Company, Amsterdam, The Netherlands.

Swanson, L.W. and P.E. Sawchenko. 1983. Hypothalamic integration: organization of the paraventricular and supraoptic nuclei. Annu. Rev. Neurosci. 6: 269-324.

Thomas, K.R. and M.R. Capecchi. 1987. Site-directed mutagenesis by gene targeting in mouse embryo-derived stem cells. Cell 51: 503-512.

Tsuchida, T., M. Ensini, S.B. Morton, M. Maldasarre, T. Edlund, T.M. Jessell, and S.L. Pfaff. 1994. Topographic organization of embryonic motor neurons defined by expression of LIM homeobox genes. Cell 79: 957-970.

Vale, W., J. Spiess, C. Rivier, and J. Rivier. 1981. Characterization of a 4l-residue ovine hypothalamic peptide that stimulates secretion of corticotropin and $\beta$-endorphin. Science 213: 1394-1397.

Wegner, M., D.W. Drolet, and M.G. Rosenfeld. 1993. POU-domain proteins: Structure and function of developmental regulators. Curr. Opin. Cell Biol. 5: 488-498.

Wilkinson, D.G. 1993. In situ hybridization. In Essential devel- opmental biology: A practical approach (ed. C.D. Stern and W.H. Hollandl, pp. 259-274, IRL Press. Oxford, UK.

Witta, S.E., V.R. Agarwal, and S.M. Sato. 1995. XIPOU2, a noggin-inducible gene, has direct neuralizing activity. Development 121: 721-730.

Yang, X., S. Yeo, T. Dick, and W. Chia. 1993. The role of a Drosophila POU homeo domain gene in the specification of neural precursor cell identity in the developing embryonic central nervous system. Genes \& Dev. 7: 504-516.

Yeo, S.L., A. Lloyd, K. Kozak, A. Dinh, T. Dick, X. Yang, S. Sakonju, and W. Chia. 1994. On the functional overlap between two POU homeo domain genes and the cell fate specification of a CNS neural precursor. Genes \& Dev. 9: 12231236. 


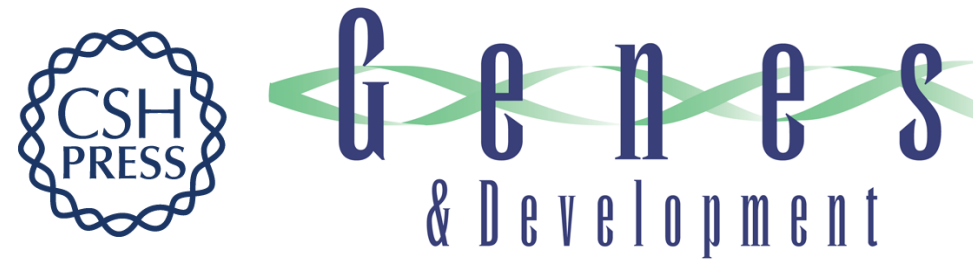

\section{Development and survival of the endocrine hypothalamus and posterior pituitary gland requires the neuronal POU domain factor Brn-2.}

M D Schonemann, A K Ryan, R J McEvilly, et al.

Genes Dev. 1995, 9:

Access the most recent version at doi:10.1101/gad.9.24.3122

References This article cites 64 articles, 21 of which can be accessed free at:

http://genesdev.cshlp.org/content/9/24/3122.full.html\#ref-list-1

License

Email Alerting Service

Receive free email alerts when new articles cite this article - sign up in the box at the top right corner of the article or click here.

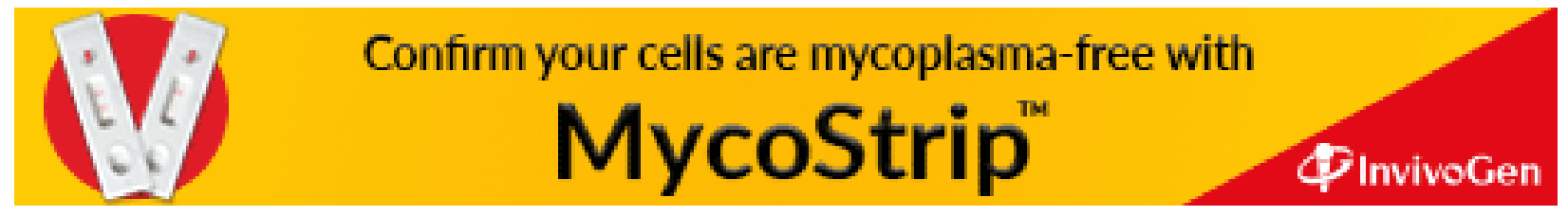

